sciendo Порівняльна професійна педагогіка 8(4)/2018 Comparative Professional Pedagogy 8(4)/2018

DOI: $10.2478 /$ rpp-2018-0056

Postgraduate Student, MAKHIRA MALYSHEVA

The Institute for Vocational Education of the National Academy of Pedagogical Sciences of Ukraine

Address: 98-a Chapaiev Ave, Kyiv, 03045, Ukraine

E-mail: m.h.malicheva@gmail.com

\title{
PROFESSIONAL TRAINING OF HOSPITALITY SPECIALISTS IN TURKISH AND UKRAINIAN VOCATIONAL SCHOOLS
}

\begin{abstract}
The article analyzes the organization of practical training for hospitality specialists in vocational schools in Turkey and presents the specificity of collaboration between vocational education institutions and tourism enterprises, which are based on the principles of responsibility, expediency of using available resources at the appropriate level, support of youth and society, expanding of opportunities for education, etc. It also outlines the main objectives of collaboration between vocational education institutions and tourism enterprises, which are aimed at integrating theory and practice, adjusting learning to reallife conditions, developing professional skills, expedient using opportunities and resources of industrial sectors, etc. In addition, it proves that vocational education and institutions and tourism enterprises have certain common and distinct views on the goals of industrial training for pupils. Based on the analysis of researches by Turkish scholars, the model of practical training for hospitality specialists in Turkey is characterized. The key problems in the organization of practical training for students at enterprises are specified. They include some differences between graduates' expectations of career in tourism and real working conditions at tourism enterprises; lack of theoretical and practical knowledge required for effective professional performance; trainees' dissatisfaction with inflexible working hours; discrepancy between types of activity and a chosen specialization; violations of social rights to meals and accommodation, etc. Some relevant recommendations for improving practical training of future hospitality specialists in Turkey and Ukraine are outlined.

Keywords: vocational education, vocational lyceums, practical training, toursim sector, hospitality specialists, tourism enterprises, Turkey.

\section{INTRODUCTION}

Nowadays, the Turkish Republic constantly develops relevant strategies for improving the quality of modern vocational education, since the country is in need of skilled workers, who should be able to operate successfully under changing industrial conditions and apply new technological knowledge and modern working methods. Dynamic progress of industrial structures requires that education systems be upgraded, investment in technological infrastructure be attracted, world progress be carefully monitored and close cooperation with the private sector be ensured. In this context, vocational education should provide the knowledge, skills and competences, which are necessary to meet the goals of economy and global labour market (Ĕgitimi araştırma, 2009, p. 11).

In Turkey, the modern concept of tourism demands that the quality of tourism services should be assured and constructive relations between tourists and staff should be established. Therefore, the implementation of these two aspects largely depends on a high
\end{abstract}


sciendo Порівняльна професійна педагогіка 8(4)/2018 Comparative Professional Pedagogy 8(4)/2018

level of vocational training of those who work in tourism sector (Christou, 1999). The latter, in turn, has the largest share in global industry of services in terms of value added, employment and investment.

\section{THE AIM OF THE STUDY}

The paper aims to analyze professional training of hospitality specialists in vocational schools in Turkey.

\section{THEORETICAL FRAMEWORK AND RESEARCH METHODS}

In the context of studying practical training of hospitality specialists in vocational schools in Turkey, those researches that highlight the trends in development of vocational education abroad attract most interest. They include some trends in the development of vocational education in China (N. Paziura); some peculiarities of teacher training in the EU countries in the late 20th century (L. Pukhovska); the results obtained from analysis on the systems of training for skilled workers in Bulgaria and Poland during the late 19th century - the 20th century (A. Kaplun); theory and practice of vocational training for the unemployed in the USA (N. Bidyuk); practical training of hospitality specialists at US universities (L. Chorna); trends in development of transnational higher education in developed English-speaking countries during the second half of the 20th century - the early 21 st century ( $\mathrm{N}$. Avshenyuk); trends in development in school education in the EU countries (O. Lokshyna), etc.

Particular attention should be paid to the study on the system of vocational education in Turkey and development of continuing education in Eastern European countries in the second half of the 20th century (T. Desiatov); the processes of shaping and developing the education system in Turkey (N. Korchynska, S. Sapozhnikova, S. Usmanova, F. Yakubova et al.).

The peculiarities of practical training for hospitality specialists were disclosed by such Turkish scholars as Ağaoğlu (1991), Özkan (1992), Kızıllırmak (2000), Küçüktopuzlu (2002), Kuşluvan (2000), Türlüoğlu (2003), Kozak ve Kızılırmak (2001), Yıldırım (2002), Çapar (2002), Gürdal (2002), Güçer (2004), Boylu (2004), Ünlüönen ve Boylu (2005), Pelit ve Güçer (2006), Özekin (2010) et al. These scholars conclude that the most important problems in tourism sector include lack of qualified staff, inadequate social rights and privileges, low wages, seasonal work, irregular working hours, unhealthy living conditions in temporary accommodation for staff, the risk of losing one's jobs due to reduced volumes of business, employment of cheaper and unskilled staff, etc. Such circumstances lead to the outflow of skilled personnel from tourism sector. In addition, over the past few years the policy of reducing staff costs has led to the situation that many tourism agencies tend to hire trainees (Kozak, 2005).

The results obtained from comparative analysis on vocational education systems abroad serve as the basis for studying the peculiarities of practical training for hospitality specialists in Turkish vocational schools and formulating relevant recommendations, which can be used to improve practical training of hospitality specialists in the context of vocational education in Ukraine.

\section{RESULTS}

In Turkey, Anatolian vocational and technical lyceums are secondary education institutions, where skilled workers are trained for four years to learn a certain profession in accordance with the objectives of the Turkish national education. If necessary, graduates can continue their education in higher education institutions and, consequently, ensure development of the national economy (Ünlüönen, \& Boylu, 2005). 
The vocational programmes in Anatolian vocational schools train students according to the requirements of the sector: they receive theoretical and practical training at lyceum for six months annually (from October to March), and then they obtain internships at tourism enterprises once the tourism season has started (from the second half of April to September). In addition, when studying in vocational education institutions, students attend training courses at tourism enterprises on certain days of the week.

The subjects, which develop general knowledge and competences necessary for all branches of the economy, are taught mainly in grades 10-11. During this period, they are in training in tourism agencies from the first week of May to the last week of September. Grade 12 offers classes aimed at obtaining professional qualifications required for a diploma. At the end of grade 12, the student who completed a curriculum and received a diploma can go on to university. Graduates also have the right to receive a certificate of qualifications obtained in a given profession / industry.

Competences received by students during a given academic year are evaluated according to certification programmes (Eğitimi araştırma, 2009, p. 15). The procedure for their certification is based on compliance with the provisions of the Law on Vocational Education (No 3308), the Law on Higher Education (No 2547), the Law on Professional Qualifications (No 5544), as well as agreements on cooperation between vocational education institutions and enterprises.

In relation to technological innovations, the content of the knowledge, abilities and skills, which are necessary for learning new professions or enhancing skills in existing ones can vary. Therefore, the acquisition of learning information can be realized in two ways: 1) through mastering knowledge in the context of implementing training programmes in the institution where students are trained; 2) through training at tourism enterprises (Pelit, \& Güçer, 2006, p. 144).

The cooperation between vocational education institutions and enterprises is aimed at enhancing the quality of vocational training, which is shown in high readiness of specialists to engage in professional activities, including in tourism sector. The programmes of cooperation, in turn, are based on the principles of responsibility, expediency of using available resources at the appropriate level, support of youth and society, expanding of opportunities for education, etc. (Gürol, 1997).

In the context of adherence to these principles, the main objectives of cooperation between vocational education and tourism enterprises are defined as follows:

- to make learning more meaningful and functional, to fill the gap between theory and practice, to associate classroom work with real working conditions,

- to secure the acquisition of general and special skills and knowledge, as well as necessary characteristics and behaviours; workplace;

- to coordinate the actvivities of educational institutions with real conditions at the

- to strengthen formal vocational training by creating relevant opportunities for vocational education in private and business sectors;

- to provide economic opportunities for students who cannot continue their education for economic reasons;

- to facilitate the transition from training to the workplace in order to use the existing opportunities and resources of society and manufacturing industries;

- to expand the scope of providing educational services to general education and vocational education and training institutions. 
sciendo Порівняльна професійна педагогіка 8(4)/2018 Comparative Professional Pedagogy 8(4)/2018

Turkish scholars indicate that today there are some problems in the organization of practical training between tourism enterprises and vocational education institutions due to different expectations of educational institutions and tourism enterprises regarding the results of internships. As rightly noted by some representatives of educational institutions, internships at enterprises are part and continuation of education (Hacioğlu, Kaşli, \& Tetik, 2008, p. 67). As stated in the Law on Vocational Education (No 3308), those students who obtain vocational education at enterprises are entitled to health insurance.

The insurance premium to students for internships at enterprises is provided by Turkey's Ministry of National Education (MoNE) and the Council of Higher Education (COHE). These payments are lower than the minimum wage, which contributes to increasing the demand of tourism sector for trainee students in order to use them as cheap work force (Buluç, 1992). Such views of some representatives of tourism enterprises contradict educational goals as for students' application of theoretical knowledge in order to improve their vocational training, acquisition of experience in using and testing the obtained knowledge in real life, in other words comprehension and application of the received information in professional environment (Çetin, 2005).

Achieving coherence between vocational education institutions and tourism enterprises in terms of common views on the organization of practical training and its results is also a basis for ensuring graduates' opportunities of employment (Sar1, 2007).

The legal basis for organizing practical training at tourism enterprises in accordance with the programmes of Anatolian vocational lyceums, which provide tourism education includes two different legislative acts, namely the Law on Vocational Education (No 3308) and Regulations on Internships in Higher Education Institutions.

The model of internship in the workplace used in Anatolian vocational lyceums, which provide training in tourism and hotel management is an educational model that can be taken as an example not only in Turkey but also in other countries with high potential of tourism sector. Teaching skills and abilities begins with the completion of theoretical education in Year 1.

Vocational schools send students to enterprises so that they can acquire necessary abilities and skills. For this purpose, they appoint a special commission whose members correspond with hotel management. This correspondence includes the information about the hotel, the duration of the internship, the number of people required, the type of work, etc. In addition, a copy of the agreement is sent to hotel companies. Once the students have obtained an internship, they are provided with the information about the rules both they and the employer must follow. According to the characteristics of the industry, those students studying in Anatolian hospitality and tourism vocational schools are trained for six months from October to March. Once the tourism season (from April to Septermber) has started, they are trained at tourism enterprises. Hospitality and tourism vocational schools tend to send students to four- and five-star hotels. However, if they are most occupied, students are sent to two- or three-star ones. With regard to the type of activity, students can work at the reception desk, provide room service or work in the bar or the kitchen. If the enterprise where the student is trained is located far from the area of his/her residence, free accommodation is provided and travel expenses are covered. It must be noted that the enterprises must pay at least $60 \%$ of the minimum wage to trainees. In addition, trainees are entitled to one day off per week, as well as 15 days of paid leave. Year 1 students are trained in all the departments of the enterprise (in the kitchen, at the reception desk, room service). Year 2 students can choose which skills to acquire. Upon completion of the internship, all students must take a test to check the acquired practical skills. Also, Year 2 
students must take a proficiency exam, whose results prove successful completion of vocational training in combination with learning outcomes from theoretical training. Year 3 and 4 students are expected to obtain theoretical knowledge for first six months. Upon successful completion of Year 4, students are entitled to a diploma. Students who failed to pass the proficiency exam must undergo practical training again (Şimşek, 2006).

As noted by some Turkish scholars (Dayığğlu, Aksu ve Köksal, Atınç Olcay, İbrahim Yildirim, Metin Sürme et al.), there are key problems in the organization of practical training for students at enterprises. They include some differences between graduates' expectations of career in tourism and real working conditions at tourism enterprises; lack of theoretical and practical knowledge required for effective professional performance; trainees' dissatisfaction with inflexible working hours, which negatively affects their professional motivation; improper use of trainees as cheap labour; discrepancy between types of activity and a chosen specialization; violations of social rights to meals and accommodation, etc.

Therefore, it is urgent to solve the above-mentioned problems and eliminate of the existing disadvantages in the organization of practical training for tourism students at tourism enterprises. Such scholars Atınç Olcay, İbrahim Yildirim, Metin Sürme have come up with specific recommendations for managers of tourism enterprises. They are the following:

- to encourage students to perform different tasks related to their specialization, to be responsible for the quality of their work and to reveal their professional potential so that they can be in demand in the labour market; perfected;

- to create relevant industrial conditions so that practical skills can be qualitatively training;

- to provide students only with tasks and duties, which correlate with practical

- to collaborate with vocational education institutions to better understand their role in improving vocational education and developing tourism education and tourism sector.

Based on the experience of Turkish vocational schools in organizing practical training, it should be noted that in Ukraine there is a similar model for organizing students' internships at enterprises, and thus there are similar problems as those which exist in Turkey.

Analyzing vocational training for hospitality specialists in Ukraine, it should be borne in mind that the potential of public private partnership regulated by legal principles of the Law of Ukraine "On Public Private Partnership" and international contracts is insufficiently used in relation to the organization of vocational training. In fact, it should assure the development of internship places, the exploitation of innovative enterprises at the existing vocational education institutions, the elaboration of modern technologies in vocational training and strengthen the role of enterprises, organizations, institutions in providing opportunities for vocational and practical training of students, etc. (Malysheva, 2017, p. 109).

\section{CONCLUSIONS}

So, the common trends in improving practical training of future hospitality specialists both in Turkey and Ukraine include the following: developing links between the system of vocational education and the labour market, strengthening social partnership in vocational education in order to reconcile the common goals of vocational tourism education in relation to training of skilled workers, who are able to ensure the integration of tourism into the area of international tourism. Therefore, it can be concluded that the specificity of collaboration between vocational education institutions and tourism enterprises is based on the principles of responsibility, expediency of using available resources at the appropriate level, support of youth and society, expanding of opportunities 
sciendo Порівняльна професійна педагогіка 8(4)/2018 Comparative Professional Pedagogy 8(4)/2018

for education, etc. In addition, the main objectives of collaboration between vocational education institutions and tourism enterprises are aimed at integrating theory and practice, adjusting learning to real-life conditions, developing professional skills, expedient using opportunities and resources of industrial sectors, etc. The conducted research proves that vocational education and institutions and tourism enterprises have certain common and distinct views on the goals of industrial training for pupils. It is specified that the key problems in the organization of practical training for students at enterprises include some differences between graduates' expectations of career in tourism and real working conditions at tourism enterprises; lack of theoretical and practical knowledge required for effective professional performance; trainees' dissatisfaction with inflexible working hours; discrepancy between types of activity and a chosen specialization; violations of social rights to meals and accommodation, etc.

Further studies should aim to disclose the specificity of organizing research training for future hospitality specialists.

\section{REFERENCES}

1. Buluç, G. (1992). Turizm ve otel işletmeciliği eğitiminde stajın önemi. Turizm Eğitimi Konferans1-Workshop 9-11. Ankara.

2. Çetin, S.. (2005). Öğrenci stajlarında yararlanılan dersler üzerine ampirik bir araştırma: Mersin üniversitesi turizm işletmeciliği ve otelcilik yüksekokulu örneği. Turizm araştırmaları dergisi, 2, 154-169.

3. Christou, E. (1999). Hospitality management education in Greece: an exploratory study. Tourism Management, 6, 683-691.

4. Ĕgitimi araştırma ve geliştirme dairesi başkanlığl, Anadolu otelcilik ve turizm meslek liselerindeki uygulama birimlerinin amacına uygunluğunun değerlendirilmesi. (2009). Ankara: MEB.

5. Gürol, M. (1997). Okul-sanayi ișbirliği. Ankara: Pegem Yayınevi.

6. Hacioğlu, N., Kaşli, M., \& Tetik, N. (2008). Türkiye'de turizm eğitimi. Ankara: Detay Yayıncilık.

7. Kozak, N. (2005). Staj Dosyası 1: Öğrencilerin yaşadıkları sorunlar, Staj Dosyası 2: Sektörün ve turizm programlarının görüşleri, Staj dosyası 3: Turizm sektöründe staj üzerine bazı görüşler. Retrieved from http://kariyer.turizmgazetesi.com/articles/article.aspx?id=25083.

8. Malysheva, M. Kh. (2017). Orhanizatsiini zasady profesiinoi pidhotovky maibutnikh fakhivtsiv hotelno-turystychnoi haluzi v Ukraini. Naukovyi visnyk Instytutu PTO NAPN Ukrainy. Profesiina pedahohika, 14, 102-110.

9. Pelit, E., \& Güçer, E. (2006). Turizm eğitimi alanında öğretmenlik eğitimi alan öğrencilerin turizm ișletmelerinde yaptıkları stajları değerlendirmeleri üzerine bir araştırma. Ticaret ve Turizm Ĕ̈itim Fakültesi Dergisi, 1, 139-168.

10. Sar1, H. (2007). Ortaögretim düzeyinde mesleki turizm eğitimi alan öğrencilerin staj sürecine adaptasyonu üzerine bir araştırma. (Yayımlanmamış yüksek lisans tezi). Ankara: T. C Gazi Üniversitesi Eğitim Bilimleri Enstitüsü Turizm İşletmeciliği Eğitimi Anabilim Dalı.

11. Șimșek, Ö. (2006). Anadolu Otelcilik ve Turizm Meslek Liselerinde Servis Bölümü Eğitiminin Sorunlarl ve Çözüm Önerileri. Ankara: Gazi Üniversitesi Sosyal Bilimler Enstütüsü.

12. Ünlüönen, K., \& Boylu, Y. (2005). Anadolu otelcilik ve turizm meslek liselerinde öğrenim gören öğrencilerin beklenti ve algılamalarındaki değişimin karşılaştırılması (2000-2001 ve 2003-2004 Öğretim Yılları). Milli Eğitim Dergisi, 133, 166. 